Instructions for authors, subscriptions and further details:

http://ijep.hipatiapress.com

\title{
Young Children about School: Whose Voices Do We Hear?
}

Anja Tertoolen, ${ }^{1}$ Jeannette Geldens, ${ }^{2}$ Bert van Oers ${ }^{1}$, Herman Popeijus ${ }^{2}$

1) VU University Amsterdam.

2) Kempel Research Centre Helmond

Date of publication: October $24^{\text {th }}, 2017$

Edition period: October 2017 - February 2018

To cite this article: Tertoolen, A., Geldens, J., van Oers, B., \& Popeijus, H. (2017). Young Children about School: Whose Voices Do We Hear?. International Journal of Educational Psychology, 6(3), 250-277. doi: 10.17583/ijep.2017.2665

To link this article: http://dx.doi.org/10.17583/ijep.2017.2665

PLEASE SCROLL DOWN FOR ARTICLE

The terms and conditions of use are related to the Open Journal System and to Creative Commons Attribution License (CC-BY). 


\section{Young Children about School: Whose Voices Do We Hear?}

Anja Tertoolen

VU University Amsterdam

Bert Van Oers

VU University Amsterdam
Jeannette Geldens

Kempel Research Centre Helmond

Herman Popeijus

Kempel Research Centre Helmond

\section{Abstract}

School is one of the important educational practices, in which children are actively involved. When we want to contribute to the development of young children's voices, we need deeper insight into the way children act as they do. Therefore, we have to distinguish how young children's voices are composed, as we proclaim that all voices are essentially polyphonic. We found children's expressions which were not corresponding with their own teachers' and parents' expressions. Many of the presented examples of non-corresponding expressions by the children, refer to situations in which resistance, one of the identifiers of voice, is shown. This article is part of a larger study we conducted on young children's voices. In our research we want to explore the content of young children's voices and the meaning they attribute to the educational contexts they are involved in. We conducted five case studies with young children, aged 5-6, in school. We have analyzed their expressions and presented our findings earlier. In this phase of our research project we are looking for possible correspondences between the children's expressions and the expressions of their teachers and parents.

Keywords: Young children, educational contexts, voice composition, agency 


\section{La Voz de los Niños Pequeños sobre la Escuela: ¿A Quién Escuchamos?}

Anja Tertoolen

VU University Amsterdam

Bert Van Oers

VU University Amsterdam
Jeannette Geldens

Kempel Research Centre Helmond

Herman Popeijus

Kempel Research Centre Helmond

\section{Resumen}

La escuela es una de las prácticas educativas importantes, en la que los niños y niñas participan activamente. Cuando queremos contribuir al desarrollo de las voces de los niños pequeños, necesitamos una visión más profunda de la forma en que los niños y las niñas actúan como lo hacen. Por lo tanto, debemos distinguir cómo se componen las voces de los niños pequeños, ya que proclamamos que todas las voces son esencialmente polifónicas. Encontramos expresiones infantiles que no se correspondían con las expresiones de sus propios maestros y padres. Muchos de los ejemplos presentados de expresiones no correspondientes por los niños, se refieren a situaciones en las que se muestra la resistencia, uno de los identificadores de voz. Este artículo es parte de un estudio más amplio que realizamos sobre las voces de los niños pequeños. En nuestra investigación, queremos explorar el contenido de las voces de los niños pequeños y el significado que atribuyen a los contextos educativos en los que están involucrados. Llevamos a cabo cinco estudios de caso con niños pequeños, de entre 5 y 6 años, en la escuela. Hemos analizado sus expresiones y presentado nuestros hallazgos. En esta fase de nuestro proyecto de investigación, buscamos posibles correspondencias entre las expresiones de los niños y las expresiones de sus maestros y padres.

Palabras clave: Niños pequeños, contextos educativos, composición de voz, agencia

2017 Hipatia Press

ISSN: 2014-3591

DOI: $10.17583 /$ ijep.2017.2665 


\section{Tertoolen et al.- Young Children about School}

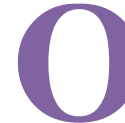

ur western society is developing more and more towards a knowledge society. Participants need a certain degree of moral and intellectual autonomy to act adequately in such a society (Hargreaves, 2003). An appropriate question for teachers and other educators is then how children could be supported to their best interest to become autonomous and responsible participants in society.

School is one of the important educational practices in modern society, in which children are actively involved. It contributes to children's socialization and the formation of their abilities to take part as autonomous and critical agents in the cultural practices they are engaged in, or will presumably be engaged in in the future. Agency refers to this critical capacity of persons to act upon the world, even to remake it to some extent, and do so purposely and reflectively in interaction with others (Holland, Lachicotte, Skinner \& Cain, 1998, p. 42). In practicing agency we see how persons respond in characteristic ways to the circumstances, relations and cultures in the given situation. Children's agency refers to children's possibilities and willingness to control their own actions, but also to change it and, when they feel the need to it, to resist the socio-cultural context they are involved in. An adult's readiness to see children as competent to do so, is an important condition for the actual manifestation of children's agency (Meadows, 2010; Rainio, 2010).

As Holland et al. (1998) have pointed out, a person's agency is closely related to a person's identity: a situated manifestation of persons' conceptions about him- or herself. Agency, and identity for that matter, can particularly be observed in a person's way of expressing or voicing his or her perspectives - consciously, objectified and purposeful - on the given situation, and the socio-cultural environment in general, in which this situation is embedded (Eteläpelto, Vähäsantanen, Hökka \& Palomieni, 2013; Wertsch, 2002). Moreover, a person's expressions offer opportunities for others to respond and change these expressions through dialogues, and hence influence the content of a person's voice, and ways of acting upon the world (Bakhtin, 1981).

Wertsch (1991, p. 90) argues that in a person's voice, voices of others resound as well. Moreover, as one's voice comes into contact with other voices, the meaning of what is said may change under the influence of those 
other voices, and so voices become more and more multi-voiced. Accordingly, voices are essentially polyphonic. Consequently, it is often unclear whose voices we actually hear when young children express their perspectives. Hence, if we want to foster their development towards autonomous and responsible agency, we need a deeper understanding of the polyphony of their voices.

When teachers want to contribute to the development of young children's agency, we need deeper insight into the way children act as they do in specific situations, and into their motives for acting. Given the dominant position of school in most children's lives, we need most of all insight into the content of their voices with respect to their school environments. As we proclaim that all voices are in essential polyphonic, we have to distinguish how young children's voices are composed. We have to distinguish the way in which the voices of others resound in children's voices first, before we are able to gain insight into their autonomous and responsible agency. Therefore, in our research we raise the following questions: (1) Which correspondences can be discovered in the voices of proximal others (parents, teachers, peers) and an individual child's voice? (2) Which expressions can be found that do not correspond to proximal others? We focus on children, aged 5-6, in school.

This article is part of a larger study we conducted on young children's voices. In our research project we want to explore the content of young children's voices and the meaning they attribute to the educational contexts they are involved in. We started our research with a literature study on young children's voices. Then we conducted a first case study to test our methods for data collection and analysis on researching attribution of meaning by young children in school. We have described how we have dealt with the issues of validity and reliability in a former part of our research. We carried out four other case studies and with the help of our coding system we described the expressed contents of these children's voices. Based on these descriptions we were able to present findings about the meanings the case study children ascribe to their education. At the same time, when children express their notions about the education they receive, the notions of important others, like teachers and parents, probably resound in children's expressions too. 


\section{Tertoolen et al.- Young Children about School}

In this article we present the results of our research on the possible resounding of parents' and teachers' voices in children's voices. First, we describe our theoretical and conceptual framework. Secondly, we present our coding system, developed for the classification and analysis of children's and adult's expressions. We describe how we analyzed the contents of the interviews which we have held with the case study children's teachers and parents. Then we present a taxonomy we have created for distinguishing and interpreting correspondences in the children's and adults' expressions, and the results we have found. Finally, we describe the answers on our research questions and we discuss our findings

\section{Theoretical Framework}

Like Bronfenbrenner (1979) and Hedegaard (2008a), we consider young children as active participants in dynamic micro-systems, like educational practices as well as their families. In these systems children encounter different kinds of related perspectives. First, the societal perspective related to the level of society with its own cultural traditions and value positions. Secondly, the institutional perspective related to the educational level with teachers and peers, and related to the level of family life with parents and other family members. By participating in different micro-systems in which children encounter different perspectives, they gradually change their motives and their competences. Subject to all these influences, children develop their perspective at an individual level, influenced by societal and institutional perspectives. Inversely they may contribute to societal and institutional perspectives in their turn.

In Figure 1 we schematically summarize our conceptual framework on research as follows: 


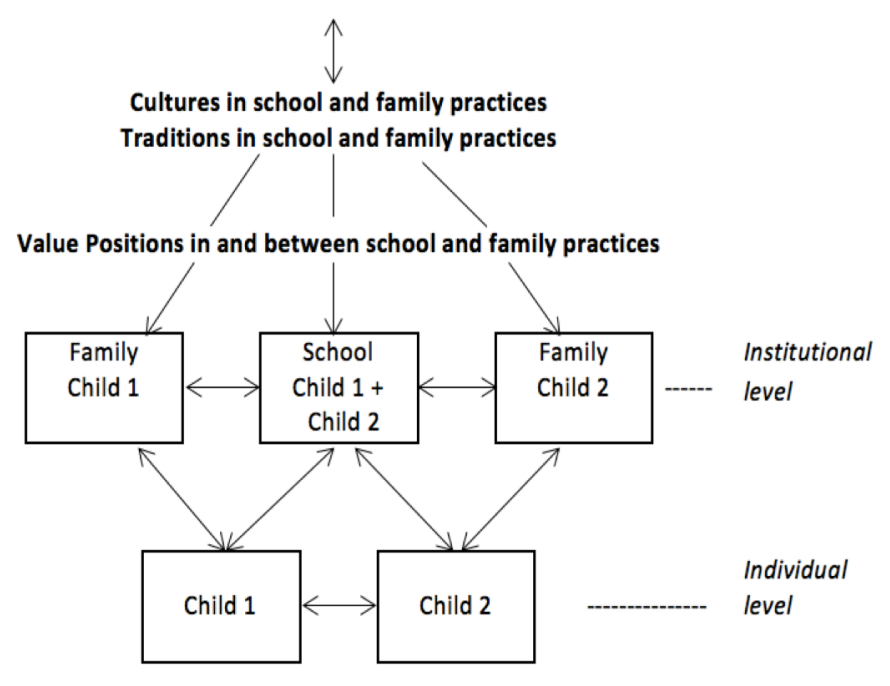

Figure 1 Children's Participation in Different Microsystems (Family and School) Encountering and Integrating Different Perspectives (Societal, Institutional, and Individual)

Figure 1 (based on Hedegaard, 2008a) positions our case-studies in a system of the dynamic relationships between an individual child and an institution as family (in our case-studies: parents) on the one hand, and an institution like school (in our case-studies: teachers) on the other hand within society with its cultures and value positions. The connecting lines in Figure 1 show the reciprocal influence, between the individual children and the institutions (family and school). They also show the reciprocal influences between the representatives in the different institutions (parents and teachers) at the institutional level. Finally, the lines show peers influencing each other at an individual level as well. This framework of children's development of perspectives is a directive of our research on the content of 


\section{Tertoolen et al.- Young Children about School}

young children's voice in educational practices, and how these voices are composed.

Cultures and traditions are reflected in a person's meaning making, or voice. Wertsch (2002) refers to narratives as cultural tools. It is impossible to express narratives without introducing other voices along with one's own voice to produce coherent meanings on a certain topic. Consequently, practicing agency as consciously voicing one's purposeful perspectives on a given situation within a socio-cultural environment, has to be considered as a form of bounded agency. It refers to the way people actively try to control their lives, and cope with difficulties resulting from "the complex interplay of e.g. cultural contexts, institutional systems, people's own attitudes, and actions in the labor and education markets, and associated support systems." (Eteläpelto et al., 2013, p. 58). People reflect their perspectives on given situations in the narratives they tell. By listening to their narratives it is possible to gain insight in their meaning making on and how they practice agency in certain situations. In order to answer our research questions, it was necessary to analyze children's as well as adult's narratives about school environments. By comparing those narratives of children and adults, we aimed to trace voices of those proximal adults resounding in a child's voice.

\section{Method}

Our research method consisted of a qualitative-interpretative approach in a flexible design. For triangulation reasons, we used multiple sources of evidence in our five case-studies (Robson, 2011; Tertoolen, van Oers, Geldens \& Popeijus, 2012; Yin, 2009). We considered each of our cases as a separate study, enabling us to investigate the dynamics of the specific context in which each child, aged 5-6, is involved.

In choosing our case-studies we had to make sure that they would open a window on the phenomena we wanted to study. Accessibility and geographic proximity were relevant criteria as well, besides the teachers' willingness to make special arrangements on behalf of the research (Yin, 2009). At the start of each case-study, the parents were informed about the research, and asked for their (written) consent for their children's participation. We granted children to participate on a voluntary basis. They 
could always withdraw from the research at any moment, and we asked for their consent to use whatever they wanted to share. We explained the children the aims of the research, being aware that ethics, power, and reciprocity are always at stake (Bertram et al, 2016).

Audiotaped semi-structured interviews were held afterwards with the children's parents and their teachers about their views on educational practices in general, and more specifically in relation to their children involved.

All data were transformed into word by word transcriptions. Qualitative data-analysis software was used for the ongoing comparative qualitative data analysis of these transcriptions (Tertoolen, Geldens, van Oers \& Popeijus, 2015; Tertoolen, van Oers, Geldens \& Popeijus, 2016).

We built a coding system to analyze children's expressions, based on three categories of the school context: children's attitude towards school activities, towards school organization, and towards teacher's roles, in a process of open coding (see Table 1). 


\section{Tertoolen et al.- Young Children about School}

Table 1

Coding System with Main Categories, Subcategories and Properties

\begin{tabular}{|c|c|c|c|}
\hline \multirow[t]{2}{*}{ Category } & \multirow[t]{2}{*}{ Subcategory } & \multirow[t]{2}{*}{ Property (and Relations) } & \\
\hline & & & $\mathbf{P} / \mathbf{F} / \mathbf{O}$ \\
\hline \multirow{12}{*}{$\begin{array}{l}\text { 1. Attitude towards } \\
\text { School Activities }\end{array}$} & 01. Affect & Suggesting & \\
\hline & & Preferring & \\
\hline & & Rejecting & \\
\hline & & Assigning & \\
\hline & & Revealing & \\
\hline & 02. Cognition & Demonstrating & \\
\hline & & Commenting & \\
\hline & & Questioning & \\
\hline & & Narrating & \\
\hline & 03. Behavior & Collaborating & \\
\hline & & Postulating & \\
\hline & & Showing & \\
\hline \multirow{6}{*}{$\begin{array}{l}\text { 2. School } \\
\text { Organization (rules / } \\
\text { routines / planning) }\end{array}$} & 04. Adoption & Following & \\
\hline & & Accepting & \\
\hline & & Imposing & \\
\hline & 05. Modification & Ignoring & \\
\hline & & Adjusting & \\
\hline & & Opposing & \\
\hline \multirow[t]{15}{*}{ 3. Teacher's Roles } & & $\mathrm{i} / \mathrm{r} / \mathrm{a}$ & \\
\hline & 06. Instructor & Obliging & \\
\hline & & Learning & \\
\hline & & Adding & \\
\hline & 07. Facilitator & Initiating & \\
\hline & & Assisting & \\
\hline & & According & \\
\hline & 08. Educator & Mediating & \\
\hline & & Attending & \\
\hline & & Complimenting & \\
\hline & & Correcting & \\
\hline & & Passing on & \\
\hline & & Care taking & \\
\hline & 09. Cultural mediator & Conveying & \\
\hline & & Exchanging & \\
\hline
\end{tabular}

Note. A relational component or a combination of relational components can be added to all the properties: P (Peers) / F (Family) / O (Other, but not the own teacher of the child). The kind of the child's expression, in relation to his teacher, is added to the properties in category 3 by: $i$ (in interaction with the teacher), $r$ (in the role of the teacher) or a (about the teacher, without the teacher being present). 
We added properties to these (sub)categories to specify children's expressions and actions, e.g. preferring, commenting, collaborating, as well as teacher's actions and intentions, regarding the case-study children, e.g. initiating, complimenting, mediating (Tertoolen et al., 2015).

In addition to this formal system for the analysis of children's expressions and (inter)actions, we also needed another, external, theory-based tool for the analysis of voice content. We formulated characteristics, or indicators, as manifestations of young children's attribution of meaning within the schoolcontext, i.e. their voice:

1. Expressing feelings and choices;

2. Sharing ideas about competences and needs;

3. Showing knowledge by pointing out, investigating, confirming, and opposing;

4. Intending to gain something related to/at the expense of others.

Finally, properties from our coding system, which associated with elements of the indicators of attribution of meaning, were included into a framework for the analysis and comparison of children's narratives within a school-context. This framework enabled us to look into children's notions their intentions and motives - and modes of expressing, in a systematic and transparent way. Table 2 shows our four indicators of attribution of meaning, related to the properties in our coding system 
Table 2

Indicators of Attribution of Meaning, Related to Characterizations of Children's Expressions (Properties With Possible Elements of Conation: Thinking, Feeling, Wanting)

\begin{tabular}{|c|c|c|}
\hline \multirow{2}{*}{$\begin{array}{c}\text { Indicators of Attribution of Meaning by } \\
\text { Children }\end{array}$} & \multicolumn{2}{|c|}{ Children's Expressions } \\
\hline & Properties & Conation \\
\hline 1. Expressing feelings and choices & $\begin{array}{l}\text { Preferring } \\
\text { Revealing }\end{array}$ & \\
\hline $\begin{array}{l}\text { 2. Sharing ideas about competences and } \\
\text { needs }\end{array}$ & $\begin{array}{l}\text { Demonstrating } \\
\text { Collaborating } \\
\text { Showing } \\
\text { Assisting } \\
\text { Attending } \\
\text { Complimenting }\end{array}$ & 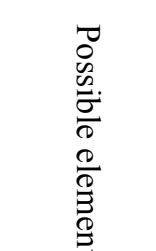 \\
\hline $\begin{array}{l}\text { 3. Showing knowledge by pointing out, } \\
\text { investigating, confirming, and } \\
\text { opposing }\end{array}$ & $\begin{array}{l}\text { Commenting } \\
\text { Accepting } \\
\text { Adding } \\
\text { Initiating } \\
\text { Exchanging }\end{array}$ & 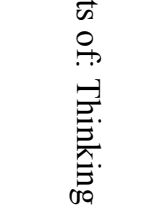 \\
\hline $\begin{array}{l}\text { 4. Intending to gain something related } \\
\text { to others/ at the expense of others }\end{array}$ & $\begin{array}{l}\text { Suggesting } \\
\text { Rejecting } \\
\text { Assigning } \\
\text { Postulating } \\
\text { Imposing } \\
\text { Opposing } \\
\text { According } \\
\text { Correcting }\end{array}$ & 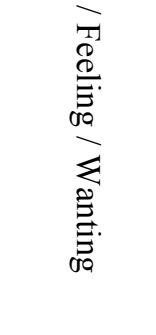 \\
\hline
\end{tabular}

The coding system, developed for the classification and analysis of children's expressions, was also used for analyzing the expressions of the adults in the interviews. We had to add one property extra, about school management. The topic school management was brought forward by the adults and not by the children.

We carried out qualitative data analyses, starting with within-case-study analysis. Followed by cross-case-studies analysis (Miles \& Huberman, 1984), based on the expressions of the case-study children (Tertoolen et al., 
2016). In the same way we analyzed the expressions of proximal (significant) others: the children's parents and teachers.

In our five case-studies we had three boys, Tom (6.5), Irfan (6.0) and Lennart (6.6), and two girls, Margareta (5.6) and Bernadette (5.7). Irfan and Margareta attended the same class. So did Lennart and Bernadette, but at a school in another city. All children performed on an average cognitive and social-emotional level, as documented in the school's monitoring systems. Their social-economic background was middle class. They all lived in family settings with both their parents. Margareta was the only one without siblings.

\section{Data Interpretation}

We started analyzing the interviews with parents and teachers at a common sense level (Hedegaard, 2008b). This level is used to look into the specific situations of the adults involved, and to reflect on the shared information and interactions in these interviews. To control for a possible researcher bias in the analyses, we invited also two independent experts in the field of early childhood, to analyze a sample of four interviews (parents and teachers) in our case-studies. By comparing these analyses of researcher and experts, we were able to compose lists of 43 leading (returning and/or outspoken) expressions by the teachers involved, and 38 leading expressions by the parents. Expressions by teachers and parents, which were not connected to school activities, school organization, or teacher's roles (see also Table 1) were left out. We also composed a combined list of 133 leading expressions by the children. Those expressions all have codes, which are related to the indicators of attribution of meaning in Table 2 . We finally selected the expressions with codes, related to the indicators 3 and 4 . We have chosen these expressions, as the indicators 3 and 4 provide the most outspoken indications for expressing voice and attribution of meaning (Kjørholt, 2005; Mayall, 2008; Tertoolen et al., 2012). We then had to compare the list of children's leading expressions with the list of teacher's and parent's expressions, to find out whether correspondences - to some extent - existed between the expressions of the children and adults within our case-studies. We wanted to make sure that this could be done in a transparent, consistent and reliable way. In line with the construction of our coding system, we 


\section{Tertoolen et al.- Young Children about School}

decided to create a taxonomy for distinguishing and interpreting corresponding expressions on four levels, that took account of the nature and content of all the expressions and their context.

- Level A. Child and adult use literally the same words or word combinations for the expression of their voice on school related matters. The situations and/or context child and adult refer to, are highly identical.

- Level B. Child and adult use words or word combinations which look alike, but are not identical (synonyms). The situations and/or context child and adult refer to, are highly identical.

- Level C. Child and adult use literally the same words or word combinations for the expression of their voice on school related matters. The situations child and adult refer to differ; the contexts are different.

- Level D. Child and adult use words or word combinations which look alike, but are not identical (synonyms). The situations child and adult refer to differ; the contexts are different.

In the lists of leading expressions we left out all the names of children and adults and randomized the sequences of collected expressions. The researcher compared all the expressions on the 4 levels. To control for a possible researcher's bias, the two independent experts were invited to compare each half of the list of children's expressions (split half: 67 expressions each out of 133). A manual for using the taxonomy for comparing the expressions was provided along with a step-to-step plan. Both experts confirmed afterwards to have followed the step-to-step plan carefully: each expression by a child was compared with each expression by a teacher and decided whether there was a correspondence at level $\mathrm{A}$, if not at level B et cetera, or no correspondence at all. After comparing all teachers' expressions, the comparing of parents' expressions was carried out in the same way. In Table 3 we present an illustration of comparing children's expressions with parents' expressions by the experts on the 4 levels: 
Table 3

Interpretations of Correspondences Between Children's and Parents' Expressions

\begin{tabular}{llllll}
\hline & \multicolumn{1}{c}{ Parents' Expressions } & \multicolumn{3}{c}{ Levels of Correspondences } \\
\cline { 2 - 5 } P02 & A & B & C & D \\
\hline $\begin{array}{l}\text { I consider it important that children like to } \\
\text { learn, are able to work. Of course the } \\
\text { ordinary subjects. Mathematics, language } \\
\text { as well as geography and whatever else }\end{array}$ & & C023 & C051 & C027 \\
C079 & & & & \\
\end{tabular}

Note. P02: The second expression in the list with parents leading expressions (P). C023, C051, C079, C027: Numbers of expressions in the list with children's leading expressions (C):
C023: [Miss $\mathrm{X}$ is asking child $\mathrm{Y}$ what $\mathrm{Y}$ has been doing during 'working hour']. Child Y: "I have been working very hard in my workbook."
C051: [Researcher: what are you good at in school?] Child Y: "Listening. Mathematics, doing sums. Well... 4 and 4 for instance, makes 8 . It is counting with working."
C079: [Child Y is doing sums on a piece of paper in the play area while playing school] Child Y shows a peer the sums on the piece of paper: "Sir, just look how well I have done?"
C027: [Miss X is showing the letter R and then the letter T]. Child Y: "That... I know as well!"

Both experts reported that they coded the lists of expressions in intervals of time (up to a maximum of 1 or 2 hours each time) to remain concentrated.

\section{Results}

\section{Quantitative Descriptors}

Looking at the outcomes of comparisons by the researcher and the two experts, we arrived at the following findings.

Researcher and experts have found correspondences between the leading expressions by the children and 39 out of the 43 leading expressions by their teachers (a similarity of 91\%). The total number of children's expressions corresponding to the teachers' expressions found by the researcher (162) was similar in 124 cases with the corresponding expressions found by the experts (a similarity of $77 \%$ ). It turned out that from the 124 similarities in 


\section{Tertoolen et al.- Young Children about School}

comparisons of expressions, in 88 cases $(71 \%)$ children's expressions were found corresponding to teachers' expressions on the same level by researcher and experts.

Researcher and experts have found correspondences between the leading expressions by the children and 30 out of the 38 leading expressions by their parents (a similarity of 79\%). The total number of children's expressions corresponding to the parents' expressions found by the researcher (94) was similar in 86 cases with the corresponding expressions found by the experts (91\% similarity). It turned out that from the 86 similarities in coding, in 69 cases children's expressions were found corresponding to parents' expressions on the same level by researcher and experts ( $80 \%$ similarity).

Out of the 124 of children's expressions found corresponding to teachers' expressions, by both researcher and experts, 49 expressions by the children (40\%) appeared to be corresponding to their own children's teacher. So $60 \%$ of children's expressions was found corresponding to other teachers, unknown to the children. This concerned all children involved in the research.

Out of the 86 of children's expressions found corresponding to parents' expressions, by both researcher and experts, 32 expressions by the children (37\%), appeared to be corresponding to their own parents. So $63 \%$ of children's expressions was found corresponding to parents of other children. This also concerned all children involved in the research.

\section{Qualitative Descriptors}

Looking at the children's expressions corresponding with teachers' expressions on level A, we noticed expressions in which children were commenting issues relevant to teachers. These were comments such as, teachers expecting older children to assist younger children, and on the other hand commenting the role of the teacher as an educator, e.g. a teacher correcting children. This was in line with children's expressions corresponding with parents' expressions. Children were commenting the rules in school, while the parents assumed that their children mostly obeyed the school rules. This was also the case even when those rules in school did not match with the rules at home. Some parents stated that their child's school had adopted many rules. Sometimes children claimed that their work 
was finished (school activities), while teachers expected children to 'add' more results and the work could be done in a more proper way. Some parents agreed that their children sometimes felt the need to rush through the activities. Both teachers and parents expected children to have a pleasant time at school.

In Table 4 we present an illustration of children's expressions corresponding with a teacher's expression $(\mathrm{T})$ and a parent's expression $(\mathrm{P})$ on level A. In the Table the scores of properties (see Table 1) and the related indicator 3 are shown too (see Table 2).

\section{Table 4}

Children's Expressions Corresponding With a Teacher's and a Parent's Expression on Level A

\begin{tabular}{|c|c|c|c|c|}
\hline Children's Expressions & $\begin{array}{l}\text { Properties a } \\
\text { Indicators }\end{array}$ & & \multicolumn{2}{|c|}{$\begin{array}{c}\text { Expressions Teachers }(\mathrm{T}) \text { and } \\
\text { Parents }(\mathrm{P})\end{array}$} \\
\hline $\begin{array}{l}\text { [Some children are } \\
\text { playing in the classroom, } \\
\text { others in the hall of the } \\
\text { school building] Lennart } \\
\text { [to a peer] "What a } \\
\text { calmness in our } \\
\text { classroom!" }\end{array}$ & Commenting & 3 & $(\mathrm{~T})$ & $\begin{array}{l}\text { "In my opinion, due to the } \\
\text { pressure of all school } \\
\text { obligations, everything } \\
\text { you'll have to do, it is not } \\
\text { always relaxing. Sometimes } \\
\text { I can't find the time to } \\
\text { create necessary calmness } \\
\text { for the children." }\end{array}$ \\
\hline $\begin{array}{l}\text { Lennart [to the researcher } \\
\text { and pointing at two peers } \\
\text { and himself]: "We all } \\
\text { like school!" }\end{array}$ & Commenting & J & $(\mathrm{P})$ & $\begin{array}{l}\text { "I expect my child to be } \\
\text { well educated and that he } \\
\text { will learn a lot. Also } \\
\text { socially. And that he will } \\
\text { like it at school. I want the } \\
\text { school to give my child a } \\
\text { pleasant time. I liked school } \\
\text { in the past as well." }\end{array}$ \\
\hline
\end{tabular}

Note. Level A: Child and adult use literally the same words or word combinations The situations and/or context referred to, are highly identical. 
Looking at the children's expressions corresponding with teachers' expressions on level B, we noticed again expressions in which children commented on teachers' opinions about the school rules and on, what teachers called, their role as an educator. Children also responded to the presented school activities which, according the teachers, were meant to support children to move to the next grade. Though parents, as well as teachers, wished for the children a pleasant stay at school, they also expected enough time and space for children's development in initial reading and mathematics. They considered this an educational assignment.

In Table 5 we present an illustration of children's expressions corresponding with a teacher's expression $(\mathrm{T})$ and a parent's expression (P) on level B. In the Table the scores of properties (see Table1) and the related indicator 3 are shown too (see Table 2). 


\section{IJEP - International Journal of Educational Psychology, 6(3) 267}

Table 5

Children's Expressions Corresponding With a Teacher's and a Parent's Expression on Level B

Children's Expressions

Properties and

Indicators

[Circle time: Miss $\mathrm{J}$ is holding up the letter $\mathrm{R}$ and then the letter T] Margareta: "That... I know as well!"

[Interview - Researcher: how was it to make a drawing after the story?]

Tom: "That's nice, for you can put all the pages together - a little book. And then you can read out loud. The children and at home, daddy and mommy."

Note. Level B: Child and adult use words or word combinations which look alike, but are not identical (synonyms).The situations and/or context child and adult refer to, are highly identical

Looking at the children's expressions corresponding with teachers' expressions on level C, we noticed mainly children's expressions corresponding with teachers' expressions about school and behavioral rules, the school activities and teacher's roles, and in particular expressions referring to (age)differentiation.

In Table 6 we present an illustration of children's expressions corresponding with a teacher's expression $(\mathrm{T})$ and a parent's expression $(\mathrm{P})$ on level C. In the Table the scores of properties (see Table1) and the related indicators 3 and 4 are shown too (see Table 2). 


\section{Tertoolen et al.- Young Children about School}

Table 6

Children's Expressions Corresponding With a Teacher's and a Parent's Expression on Level C

Children's Expressions

Properties and Indicators
[Researcher: "what is not going too well at school?"] Tom: "Well, ehmmmm... those difficult tasks. Well, ehm... folding... A... tractor."

[Miss $\mathrm{C}$ is asking the children what materials have to be provided in the play area to play school. Difficult jigsaw puzzles?] Bernadette: "But only for the oldest children, then!"
Expressions Teachers $(\mathrm{T})$ and Parents (P)
Commenting $\quad 3 \quad(\mathrm{~T})$ "There are a lot of things children don't know yet and then they won't choose them. Sometimes it takes too long. So, a folding activity, or cutting an art work, we sometimes just present them and then the children just have to carry out those activities."

Commenting 3 (P) "Some time ago, my child asked for more difficult jigsaw puzzles, but she wasn't allowed, for she was a youngest child or a middle... I don't know. But if my child is certain that she can handle this difficult puzzle, then she should be challenged. That fuzz about a puzzle, I think it's stupid. They are sometimes too rigid about those things at school. I am a bit more flexible."

Note. Level C: Child and adult use literally the same words or word combinations. The situations child and adult refer to differ; the contexts are different.

Looking at the children's expressions corresponding with teachers' expressions on level D, we noticed a wide range of children's as well as teachers' and parents' expressions. Level D expressions by teachers and 
parents showed that teachers intended to offer children a lot. Not only in the cognitive sense, but mainly in pedagogical sense, like supporting selfconfidence, being sportsmanlike, and they proclaimed that all children had the right to be. The teachers also intended to provide an agreeable live and working climate. The parents shared these notions as well.

In Table 7 we present an illustration of children's expressions corresponding with a teacher's expression $(\mathrm{T})$ and a parent's expression $(\mathrm{P})$ on level D. In the Table the scores of properties (see Table1) and the related indicators 3 and 4 are shown too (see Table 2). 


\section{Tertoolen et al.- Young Children about School}

\section{Table 7}

Children's Expressions Corresponding With a Teacher's and a Parent's Expression on Level D

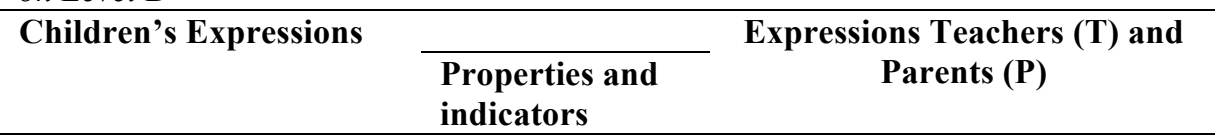

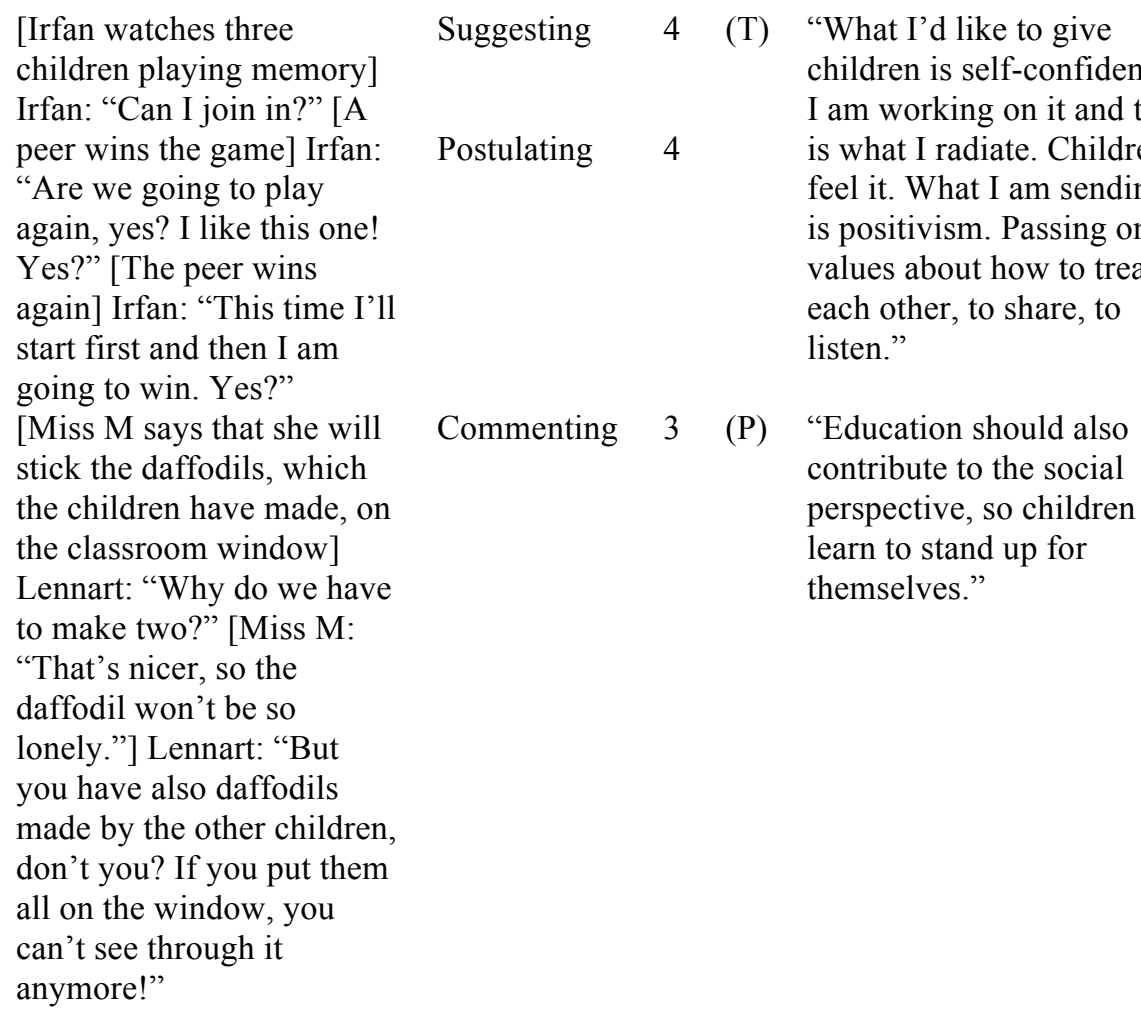

Note. Level D: Child and adult use words or word combinations which look alike, but are not identical (synonyms). The situations child and adult refer to differ; the contexts are different.

\section{Non-Corresponding Expressions}

Not all children's expressions were found corresponding (according to researcher and experts) to the adults' expressions. Out of the total of 133 
children's leading expressions, 40 expressions (30\%) appeared not to be corresponding - or only on a minor element - with teachers' or parents' expressions. This concerned the following kinds of expressions:

Five non-corresponding expressions referred to the daily routines in school, school activities, school organization and teachers' roles. Though, other comparable children's expressions were found corresponding with teachers' expressions (see Table 5: Margareta).

Seven non-corresponding expressions referred to expressions in which the children were searching for boundaries about what is or is not permitted within the school contexts. The teachers mostly were correcting the children:

1. The teacher tells the children to stay on their chairs during circle time. Margareta is lying on the floor making noises. The teacher tells Margareta to sit down. Margareta rises, sits on her chair, sighs very loudly and slips from her chair again.

Four expressions by Irfan were not found corresponding. One of these expressions was as follows:

2. Irfan, in a small group of children, is making figures with colored beads (compulsory activity). His classroom assistant asks him what he is creating. Irfan (pulling up his shoulders): "I am making an Arab letter." The classroom assistant: "It looks like a little heart to me." Irfan sweeps all the beads together at once. Irfan: "I am making a Ferrari. And a pistol. Oh yes, and a small trunk on the side of the car."

Five non-corresponding expressions were made by the children referring to the activity with photographs about what they considered important in school:

3. Lennart is looking at his photographs: "Oh, all the prices (cups and medals) and the shining little fish (aquarium). Oh, take a good look: the tiger-fish. And here is Bernadette (peer), and another Bernadette and Jan (peer and best friend). Oh, the 
toilets... and musical instruments. The classroom and miss Cecile, oh, and the television."

Eight non-corresponding expressions referred to interactions with their peers:

4. Tom is coloring a triangle: "Look Maaike (peer), how well done!"

5. Miss Magda presents Bernadette a yellow hoop. Elza (peer and friend) has a red one. Bernadette wants to have the red one instead and starts to pull it from Elza's hands. While Elza is letting it go, Bernadette falls backwards.

In three non-corresponding expressions the children indicated what they wanted and did not want to do in reaction to a teacher's assignment. The word 'wanting' was explicitly expressed:

6. The children have to draw one of the animals in the water tray: a frog or a seal (compulsory activity). Margareta: "I don't want to." Margareta starts drawing a shark (as she explains later on).

7. Miss Cecile is looking at the lotto Lennart and Jan have made (in the hallway). The lotto is positioned in a horizontal way. Lennart and Jan have left the hallway. Miss Cecile shifts the lotto in a vertical position. Lennart and Jan return to the hallway. They bring back the lotto into the horizontal position. Lennart: "We don't want it that way. We want it like this."

Finally, there are eight non-corresponding expressions, referring to feelings towards their schools and their ideal schools. Whilst talking about their ideal schools, the children also explicitly expressed the word 'wanting':

8. Irfan: "I would like to play with a tree. To climb it (on the school premises). I would do it with Tarzan. I want to have a fight with Tarzan." 
9. Bernadette: "I would like to have my cat around in school, then I could play with her all day."

The possible meanings and explanations of the analyses and interpretations of these results of corresponding and non-corresponding expressions, will be discussed in the next section.

\section{Discussion and Conclusion}

We started this article with the following questions: (1) Which correspondences can be discovered in the voices of proximal others (parents, teachers, peers) and an individual child's voice? (2) Which expressions can be found that do not correspond to proximal others?

To answer the first research question: illustrations of corresponding expressions between children's and teachers' and parents' expressions were presented in the Tables 4-7. Looking at the different Tables as illustrations of different types of expressions, we saw that many of the corresponding teachers' and parents' expressions referred to the perspectives on an institutional level: the school (Bronfenbrenner, 1979; Hedegaard, 2008a), see also Figure 1. We saw the same in children's corresponding expressions (Tables 3-5). In Table 7 the teacher and parents shared their expressions at a societal level of perspectives, whilst the corresponding children's expressions referred to the institutional level of perspectives (Figure 1). We found correspondences in expressions of children, their teachers and parents concerning the school activities, school organization, and teachers' roles. Correspondences in expressions concerned mainly school organization. In the children's voices the rules and routines in school resounded: how to accomplish your school work, when and how to clean the classroom, how to act om the school premises and so on. In children's voices the perspectives of their teachers and parents concerning the importance of doing well in school and to be educated in school subjects, resounded as well (Tables 5-6).

Looking at the correspondences in expressions between the children and adults, we noticed that $60 \%$ of the children's expressions were corresponding with expressions of a teacher, unknown to the children. Also $63 \%$ of the children's expressions were corresponding to expressions of 


\section{Tertoolen et al.- Young Children about School}

other children's parents. In analyzing the narratives of both teachers and parents, we found similarities in those narratives. Parents and teachers agreed, to a large extent, upon the importance of acquiring academic skills to be able to move to the next grade in school, keeping to the school rules and routines, offering children an agreeable school time with lots of possibilities to play with peers, and supporting children to become self-confident and to stand up for themselves. Issues that were obviously related to common societal or institutional perspectives of adults in general, and which resounded in children's voices as well. It is plausible to interpret this fact as an indication of young children's access to social representation (Moscovici, 1981) about school, which they obviously share with adults of their community and they can use as a source for their actions and expressions.

At the same time children expressed resistance to some extent. Sometimes they discussed the school rules and why they had to keep to them, or they discussed the amount, as well as the relevance of the work, they had to accomplish (Table 7). Discussion is a form of resistance and in that sense an appropriate label for indicator 3: showing knowledge by pointing out, investigating, confirming, and opposing.

In answer to our second research question, we also discovered children's expressions that did not correspond with the expressions of proximal others. We found children's expressions which were not corresponding with their own teachers' and parents' expressions, nor with the teachers' and parents' expressions of the other case-study children. Many of the presented illustrations of non-corresponding expressions by the children referred to situations in which resistance was shown openly. In the presented noncorresponding expressions 1-2 and 5-7 the children tried to achieve a personal goal, resisting - to some extent - the intentions of the teacher or a peer: sitting still during circle time, accepting a yellow hoop handed over by the teacher, positioning a lotto in a horizontal way. Hedegaard (2008a) refers to this kind of outspoken resistance as an expressed conflict, when a child is not able to do what he wants to do in line with his intentions. Conflict is in that sense an appropriate label for indicator 4: intending to gain something related to or at the expense of others. It is a strong indication for children's authentic voice and agency. 
Resistance is possible in a school-context which children are able to control to a certain extent (Holland et al., 1998) and, when children feel the need to it and are enabled, to remake it to a certain extent as well (Meadows, 2010; Rainio, 2010). In expressing resistance, in discussions and in conflicts, children may also show moral and intellectual autonomy to a certain extent. Teachers have to deal with these kinds of behavior, balancing between the rules and restrictions in schools for the benefit of all, and the need for individual children to develop into autonomous and social citizens in our western society.

By comparing children's expressions systematically with teachers' and parents' expressions, we gained insight in types of expressions of all participants involved, as well as the correspondences between the voices of teachers and parents (proximal others) and the voices of the individual children. In the results section we have described the steps we have taken to approach the essence of the narratives of the proximal others, compiled in lists of leading expressions by teachers and parents, and the measures we have taken for expanding transparency and reliability. At the same time, the results of our case-study research cannot be generalized to all young children and their parents and teachers. A survey-study in the future, with many more children in various circumstances, involved over a longer period of time, could probably benefit from the outcomes of this case-study research.

\section{References}

Bakhtin, M. M. (1981). The Dialogic Imagination. Four Essays by M.M. Bakhtin. Edited byM. Holquist. Austin: University of Texas Press. Bronfenbrenner, U. (1979). The ecology of human development. Experiments by nature and design. Cambridge, Mass.: Harvard University Press. Bertram, T., Formosinho, J., Gray, C., Pascal, C., \& Whalley, M. (2016). EECERA ethical code for early childhood researchers. European Early Childhood Education Research Journal, 24(1), iii-xiii. doi:10.1080/1350293X.2016.1120533 
Eteläpelto, A., Vähäsantanen, K., Hökkä, P., \& Paloniemi, S. (2013). What is agency? Conceptualizing professional agency at work. Educational

Research Review, 10, 45-65. doi:10.1016/j.edurev.2013.05.001

Hargreaves, A. (2003). Teaching in the Knowledge Society: Education in the Age of Insecurity. New York: Teachers' College Press.

Hedegaard, M. (2008a). A cultural-historical theory of children's development. In M. Hedegaard \& M. Fleer, Studying Children: A Cultural-Historical Approach (pp. 10-29). Maidenhead: Open University Press.

Hedegaard, M. (2008b). Principles for interpreting research protocols. In M. Hedegaard \& M. Fleer, Studying Children: A Cultural-Historical Approach (pp. 46-64). Maidenhead: Open University Press.

Holland, D., Lachicotte Jr., W., Skinner, D., \& Cain, C. (1998). Identity and Agency in Cultural Worlds. Cambridge/London: Harvard University Press.

Kjørholt, A. T. (2005). The competent child and 'the right to be oneself': reflections on children as fellow citizens in an early childhood centre. In A. Clark, A.T. Kjørholt, \& P. Moss (Eds.), Beyond listening. Children's perspectives on early childhood services (pp. 151-173). Bristol: The University Press.

Mayall, B. (2008). Conversations with children. Working with generational issues. In P. Christensen \& A. James (Eds.) ( $2^{\text {nd }}$ ed.), Research with children. Perspectives and practices (pp. 109-124). London:

Routledge.

Meadows, S. (2010). The Child as Social Person. London: Routledge. Miles, M. B., \& Huberman, A. M. (1994). Qualitative data analysis $\left(2^{\text {nd }}\right.$ ed.). London: Sage.

Moscovici, S. (1981). On social representation. In J. P. Forgas, Social Cognition (pp. 181-209). New York: Routledge.

Rainio, A. P. (2010). Lionhearts of the playworld. An ethnographic case study of the development of agency in play pedagogy. Helsinki: University Print.

Robson, C. (2011). Real world research ( $3^{\text {rd }}$ ed.). Chichester: Wiley. Tertoolen, A., Geldens, J., van Oers, B., \& Popeijus, H. (2015). Listening to Young Children's Voices: The Evaluation of a Coding System. 
International Journal of Educational Psychology, 4(2), 113-141. doi:10.17583/ijep.2015.1500

Tertoolen, A., van Oers, B., Geldens, J., \& Popeijus, H. (2012). Building a method for researching attribution of meaning by children aged 5 to 6 in school. European Early Childhood Education Research Journal, 20(1), 115-131. doi:10.1080/1350293X.2012.650015

Tertoolen, A., van Oers, B., Geldens, J., \& Popeijus, H. (2016). Exploring the Content of Young Children's Multidimensional Voice Related to School Contexts. Research \& Reviews: Journal of Educational Studies, 2(1), 6-17.

Wertsch, J. V. (1991). Voices of the mind. Sociocultural approach to mediated action. Cambridge, MA: Harvard University Press.

Wertsch, J. V. (2002). Voices of collective remembering. Cambridge: University Press.

Yin, R. K. (2009). Case study research. Design and methods $\left(4^{\text {th }}\right.$ ed.). Thousand Oaks, California: Sage.

Anja Tertoolen is Manager Research Centre at the University of Applied Sciences iPabo in Amsterdam, Netherlands.

Jeannette Geldens is Lecturer at the Kempel University of Applied Sciences, Kempel Research Center, Helmond, Netherlands.

Bert van Oers is Professor of Cultural-historical Theory of Education. Faculty of Psychology and Education, Department of Research and Theory in Education. VU University Amsterdam, Netherlands.

Herman Popeijus is Lecturer emeritus, Kempel University of Applied Sciences, Kempel Research Center, Helmond, Netherlands.

Contact Address: Anja Tertoolen. University of Applied Sciences iPabo. Email: a.tertoolen@ipabo.nl 